\title{
Proliferation and apoptosis in the rabbit ovary after administration of T-2 toxin and quercetin
}

\author{
A. Leśniak-Walentyn ${ }^{1}$, A. Kolesarova ${ }^{2}$, M. Medvedova ${ }^{2}$, N. Maruniakova ${ }^{2}$, M. Capcarova $^{2}$, \\ A. Kalafova ${ }^{2}$ A. Hrabia ${ }^{1,4}$ and A.V. Sirotkin ${ }^{3}$ \\ ${ }^{1}$ University of Agriculture in Krakow, Department of Animal Physiology and Endocrinology \\ Al. Mickiewicza 24/28, 30-059 Kraków, Poland \\ ${ }^{2}$ Slovak University of Agriculture in Nitra, Department of Animal Physiology \\ Tr. A. Hlinku 2,949 76 Nitra, Slovak Republic \\ ${ }^{3}$ Institute of Genetics and Reproduction of Farm Animals, Animal Production Research Centre Nitra \\ Hlohovecka 2, 94992 Lužianky, Slovak Republic
}

KEY WORDS: T-2 toxin, quercetin, proliferation, apoptosis, ovary, rabbit

Received: 25 February 2013

Revised: 13 June 2013

Accepted: 2 September 2013

${ }^{4}$ Corresponding author: e-mail:

rzhrabia@cyf-kr.edu.pl; annahrabia@hotmail.com
ABSTRACT. T-2 mycotoxin, a natural contaminant of cereals and agricultural products, is known to exhibit the severest toxicity and the lowest $\mathrm{LD}_{50}$ value among trichothecenes. Since quercetin has been reported to have strong antioxidant properties, the effect of quercetin and T-2 toxin on rabbit ovarian cell proliferation and apoptosis was assessed. In the ovaries, proliferating cells were analysed immunocytochemically (proliferating cell nuclear antigen as a marker) and apoptotic cells by the terminal deoxynucleotidyl transferase (TdT)-mediated biotinylated deoxyuridine triphosphates (dUTP) nick endlabeling (TUNEL) method. It was found that: 1. a single dose of T-2 toxin (0.08 $\mathrm{mg} \cdot \mathrm{kg}^{-1}$ body weight (BW) $72 \mathrm{~h}$ before slaughter) decreased cell proliferation, 2. chronic exposure to quercetin ( $1 \mathrm{mg} \cdot \mathrm{kg}^{-1} \mathrm{BW} ; 90$ days, 3 times per week) results in increased cell proliferation and reduced cell apoptosis, 3. quercetin has the potential to attenuate T-2 toxin-induced proliferation arrest. To clarify the mechanism of T-2 toxin and quercetin action in the rabbit ovary, further experiments are necessary.

\section{Introduction}

As common phytopathogens, Fusarium species cause difficult to control cereal crop contamination in different parts of the world (Pestka, 2007). Fusarium mycotoxins, i.e. trichothecenes, are known to occur in food and feed mixtures, including grain-based foods and animal products (Labuda et al., 2009; Tancinova and Labuda, 2009). Since the presence of trichothecenes as natural pollutants has been associated with human and animal toxi- coses, many serious concerns remain to be considered regarding the impact of these fusariotoxins on animal health, as well as the economic aspect of animal production. Among trichothecenes, T-2 toxin exhibits the severest toxicity (Kosuri et al., 1971), and the lowest $\mathrm{LD}_{50}$ value. It has been claimed to cause infertility as well as increased embryonic and foetal death in pigs (Weaver et al., 1978). What is more, studies carried out on birds showed that T-2 toxin-induced toxicity may lead to disruption of follicle maturation, follicle degeneration, and oviduct 
regression (Vanyi et al., 1994). In rabbits, T-2 toxin has been reported to impair ovarian function, inhibiting production of progesterone (Szilagyi et al., 1994), which may suggest a role of this mycotoxin as an endocrine disruptor.

T-2 toxin is known to induce its toxicity by inhibition of DNA, RNA, and protein synthesis due to its ability to bind to the eukaryotic 60S ribosomal subunit (Witt and Pestka, 1990; Sudakin, 2003). Moreover, it has been suggested that T-2 toxin may induce cell death by triggering apoptosis (Albarenque and Doi, 2005; Huang et al., 2007) mostly through oxidative pathways (Sehata et al., 2005; Chaudhari et al., 2009; Wu et al., 2011). Owing to its amphipathic nature, T-2 toxin could exert its cytotoxicity by acting on cell membranes causing haemolysis (DeLoach et al., 1989). The in vitro study of Tiemann et al. (2003) suggests that trichothecenes have a direct effect on the viability of porcine uterine cells, causing swollen mitochondria, disrupted cell membranes, and numerous vacuoles. The level of T-2 toxicity is related to the animal species, age, exposure route and dose.

A number of studies demonstrate that natural products from plants such as flavonoids have antioxidative properties. Quercetin is a flavonoid that exhibits strong antioxidative, anti-inflammatory effects and has been proposed to be a potential anti-cancer agent (Erlund et al., 2004).

To our knowledge, no study has evaluated direct effects of T-2 toxin and quercetin on rabbit ovarian cell functions in vivo. Therefore, the aim of the study was to investigate the effect of chronic application of quercetin and a single dose of T-2 toxin on cell proli-feration and apoptosis in the rabbit ovary. Additionally, the ability of quercetin to attenuate the effects of T-2 toxin was examined.

\section{Material and methods}

\section{Chemicals}

Quercetin (Sigma-Aldrich, Germany), T-2 toxin (Romer Labs Division Holding GmbH, Tulln, Austria), mouse monoclonal antibody against proliferating cell nuclear antigen (Novocastra Laboratories, Newcastle upon Tyne, UK), biotinylated goat anti-mouse immunoglobulins, normal goat serum, Vectastain $\mathrm{ABC}$ kit (Vector Laboratories, Burlingame, USA), in situ cell death detection kit, POD (Roche Diagnostic, Mannheim, Germany) were used. All of the other reagents were obtained from ICN Biomedicals (Aurora, IL, USA), Sigma (St. Louis, MO, USA) or POCH (Gliwice, Poland).

\section{Animals}

Adult female rabbits $(n=20)$ of meat line M91, maternal albinotic line (crossbreed New Zealand White, Buskat rabbit, French Silver) and paternal acromalictic line (crossbreed Nitra's rabbit, Californian rabbit, Big Light Silver) from an experimental farm of the Animal Production Research Centre Nitra (Slovak Republic) were used. Rabbits, age: 150 days, weighing $4.00 \pm 0.5 \mathrm{~kg}$, were housed in individual flat-deck wire cages under a constant photoperiod of $12 \mathrm{~h}$ of daylight, temperature $20-24^{\circ} \mathrm{C}$ and humidity $55 \% \pm 10 \%$. The animals were randomly divided into the control group without quercetin or T-2 toxin, and three experimental groups that received intramuscularly injected quercetin $-1 \mathrm{mg} \cdot \mathrm{kg}^{-1}$ body weight (BW) for 90 days, 3 times per week, T-2 toxin $-0.08 \mathrm{mg}$. $\mathrm{kg}^{-1} \mathrm{BW} 72 \mathrm{~h}$ before slaughter, or their combination: quercetin $-1 \mathrm{mg} \cdot \mathrm{kg}^{-1} \mathrm{BW}, 90$ days, 3 times per week $+\mathrm{T}-2$ toxin $-0.08 \mathrm{mg} \cdot \mathrm{kg}^{-1} \mathrm{BW}$, single dose after a 90 -day period, $72 \mathrm{~h}$ before slaughter. The dose of T-2 toxin in the study was established to reflect the natural exposure of animals to $\mathrm{T}-2$ toxin in rabbit feed, whereas the chosen dose and exposure period of quercetin were based on literature data (Choi and Li, 2005; Knab et al., 2011; Petruska and Capcarova, 2012). Institutional and national guidelines for the care and use of animals were followed, and all experimental procedures were approved by the State Veterinary and Food Institute of Slovak Republic, no. 3398/11-221/3 and ethics committee. The ovaries were fixed in freshly prepared $4 \%$ $(\mathrm{v} / \mathrm{v})$ buffered formalin, processed and embedded in paraffin. Tissue sections were examined for proli- ferating and apoptotic changes, as previously described by Hrabia et al. (2011).

\section{Immunostaining for PCNA}

Ovarian sections $(6 \mu$ mthick $)$ were deparaffinized in xylene, rehydrated through a graded series of ethanol and rinsed with water. Endogenous peroxidase activity was blocked with $0.5 \% \mathrm{H}_{2} \mathrm{O}_{2}$ in methanol for $10 \mathrm{~min}$ at room temperature. After washing with water, the slides were heated in citric buffer ( $\mathrm{pH}$ 6.0, $75^{\circ} \mathrm{C}, 20 \mathrm{~min}$ ). Non-specific binding was blocked using 5\% (v/v) normal goat serum in TBST buffer (Tris buffer saline $+0.1 \%$ Tween 20, RT, $10 \mathrm{~min}$ ). The slides were incubated for $60 \mathrm{~min}$ with specific mouse monoclonal antibody against proliferating cell nuclear antigen (PCNA) at a 1:150 dilution. The ovarian sections were then washed with TBS and incubated with biotinylated goat anti-mouse antibody (35 min, dilution 1:300) followed by Vectastain ABC kit $(30 \mathrm{~min})$. The colour reaction was developed with diaminobenzidine (DAB) and $\mathrm{H}_{2} \mathrm{O}_{2}$. Slides were 
dehydrated through a graded series of ethanol, placed into xylene, and cover-slipped with DPX. The negative control was prepared by replacement of the primary antibody with TBST. Sections were analysed under a light microscope (Jena Zeiss, Germany). Proliferating cells (PCNA-positive) were counted with a computerized image analysis system (MultiScanBase v. 14.02, Computer Scanning System, Warsaw, Poland) on 10 random areas $(50 \times 50 \mu \mathrm{m})$ of each examined ovarian stroma and averaged for each rabbit. The mean value was calculated for each group.

\section{TUNEL assay}

Deparaffinized and rehydrated slides $(6 \mu \mathrm{m}$ thick) were incubated with proteinase $\mathrm{K}(20 \mu \mathrm{g}$ - $\mathrm{ml}^{-1}$ ) in $10 \mathrm{mM}$ Tris- $\mathrm{HCl}, \mathrm{pH} 7.4$ at $37^{\circ} \mathrm{C}$ for $20 \mathrm{~min}$, and next apoptotic cells were detected with the terminal deoxynucleotidyl transferase (TdT)mediated biotinylated deoxyuridine triphosphates (dUTP) nick end-labeling (TUNEL) method using the in situ cell death detection kit, POD, according to the manufacturer's instructions. The control was prepared by omitting the TdT. The colour reaction was developed by incubation with $\mathrm{DAB}$ and $\mathrm{H}_{2} \mathrm{O}_{2}$ solution. The apoptotic (TUNEL-positive) cells were analysed and counted on slides in the same way as proliferating cells.

\section{Statistical analysis}

Results were analysed statistically by one-way ANOVA followed by Duncan's multiple range test using SigmaStat 2.03 (SystatSoftwere GmbH, Germany). Differences were considered to be significant at $p<0.05$. The data are presented as means \pm SEM from 5 animals.

\section{Results}

\section{Cell proliferation}

Immunohistochemical labeling of PCNApositive cells showed their presence in the ovarian stroma and in the wall of the follicles at different developmental stages. In the early stage of development, the primordial follicles exhibited strong PCNA immunoreactivity in the oocytes (Figure 1A). In primary to secondary follicles, PCNA staining was detected in granulosa layers as well as in the nuclei of some oocytes (Figure 1B). Increased PCNA immunopositivity was found in the granulosa layer of antral follicles, whereas the theca interna showed rare PCNA-labeled cells in this group of follicles (Figure 1C). Proliferating cells were less abundant in the granulosa and theca layers of large,

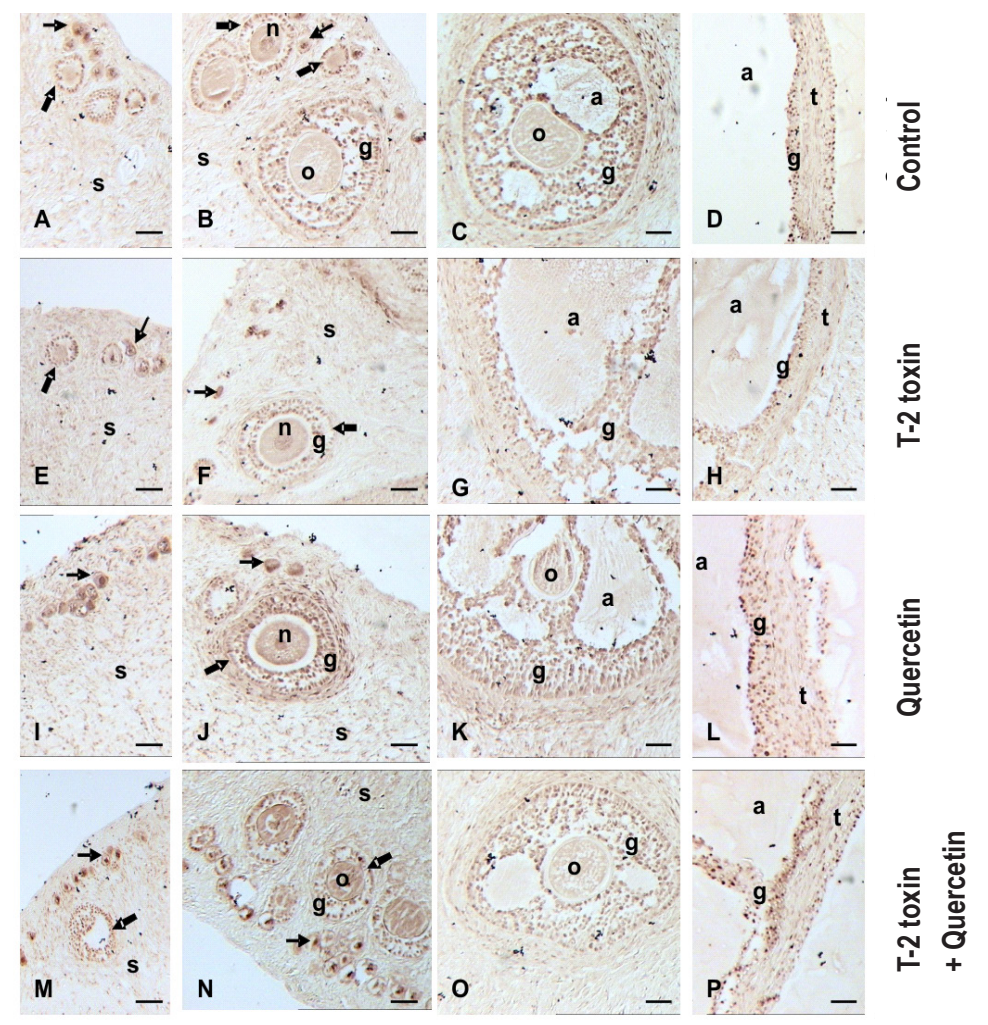

Figure 1. Immunohistochemical localization of PCNA-positive cells in rabbit ovary after T-2 toxin and quercetin treatments. A, B, E, F, I, J, M, $\mathrm{N}$ - remarkable PCNA localization detected in majority of primordial follicles (thin arrows) and in nuclei of some oocytes and granulosa cells of primary to secondary follicles (thick arrows). C, G, K, O - extensive PCNA labeling detected mainly in granulosa cells of preantral and antral follicles. D, H, L, P - PCNA-positive cells more abundant in the granulosa than in theca cells of preovulatory follicles. Symbols: a - antrum, $g$ - granulosa, $n$ - nucleus, 0 - oocyte, $s$ - stroma, $t$ - theca. Scale bar: $50 \mu \mathrm{m}$ 
preovulatory follicles (Figure 1D), and there was no marked PCNA immunoreactivity in the oocytes of these follicles. In atretic follicles, theca and granulosa cells showed diminished PCNA positivity.

The intensity of PCNA staining in the wall of the follicles at different developmental stages differed among treatment groups. Proliferating cells were less abundant in the T-2 toxin-treated group (Figure $1 \mathrm{E}-\mathrm{H}$ ) than in the control group (Figure 1A-D), quercetin-treated group (Figure 1I-L), and T-2 toxin + quercetin-treated group (Figure 1M-P). There were no variations in immunoreactivity in follicles when comparing the T-2 toxin + quercetin-treated (Figure 1M-P) and control groups, whereas in the quercetin-treated group (Figure 1I-L) PCNA-positive cells occurred in greater number in comparison with the control.

The differences in the number of proliferating cells per unit area $(50 \times 50 \mu \mathrm{m})$ of ovarian stroma among examined groups, presented in Figure 2, were similar to the differences in the number of PCNA-positive cells in the ovarian follicles.

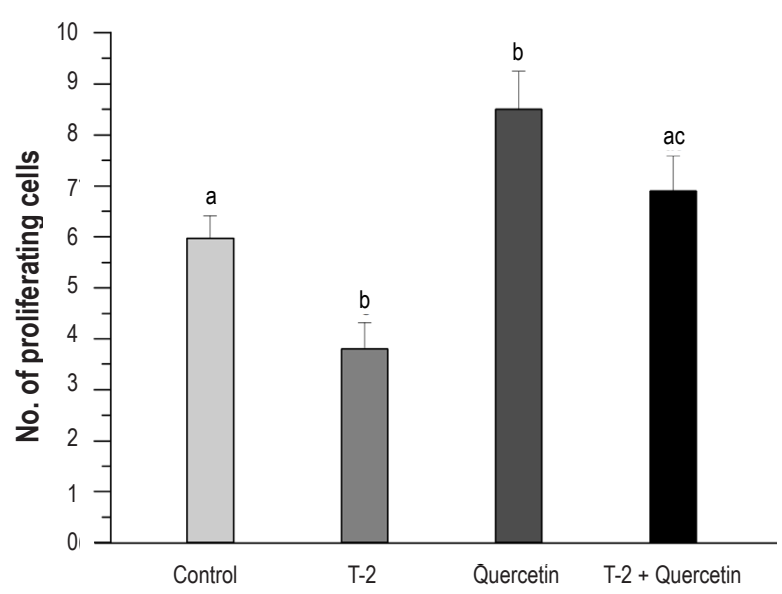

Figure 2. Effect of T-2 toxin and quercetin on number of proliferating cells in the ovarian stroma. Each value represents the mean \pm SEM from 5 rabbits; values with different superscript letters differ significantly $(p<0.05)$

\section{Cell apoptosis}

TUNEL-positive cells were detected in the ovarian stroma and in the wall of the follicles at different stages of development. The primordial

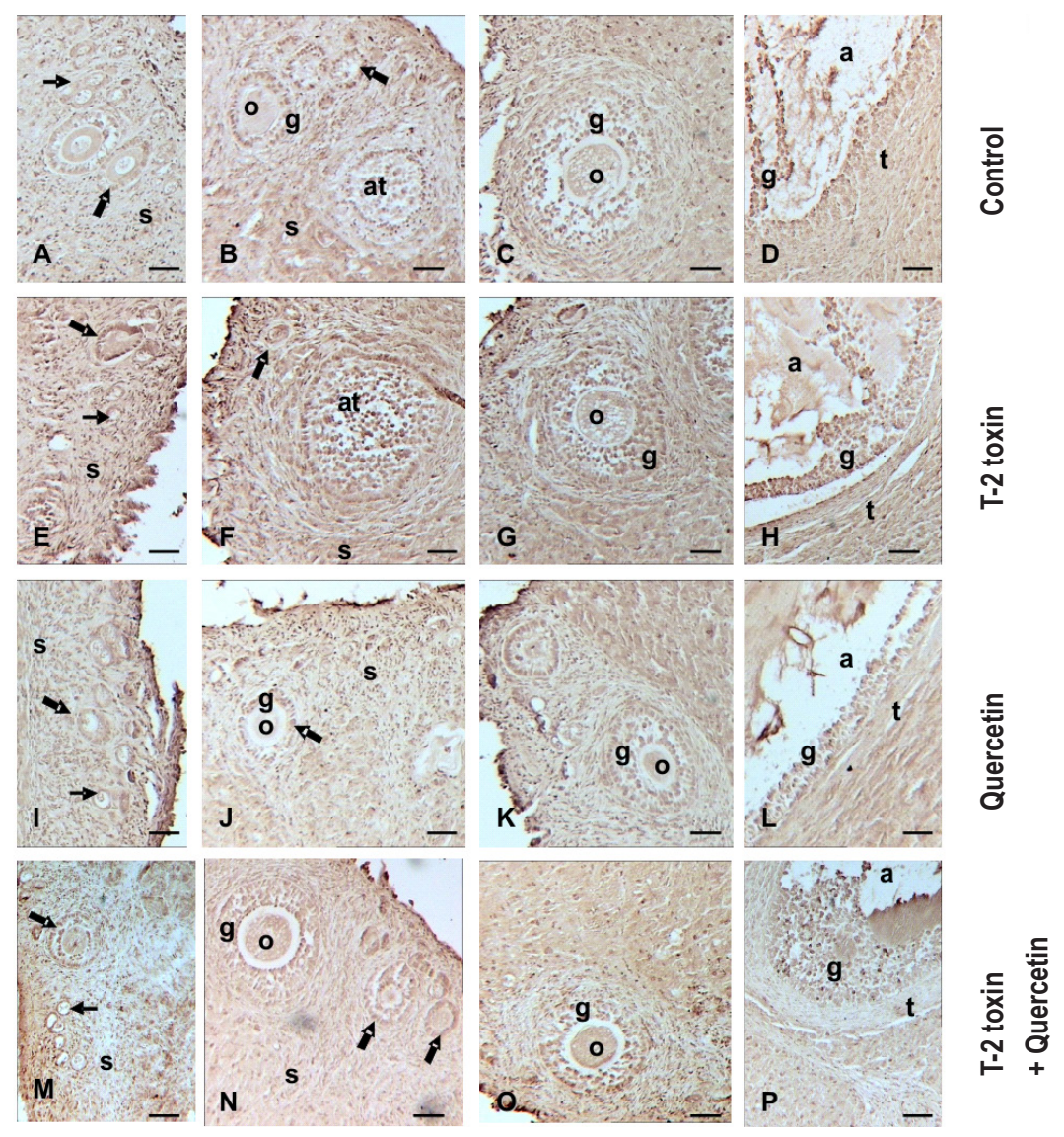

Figure 3. Immunohistochemical localization of TUNEL-positive cells in rabbit ovary after T-2 toxin and quercetin treatment. A, B, E, F, I, J, M, Napoptotic cells mainly presented in the primordial follicles (thin arrows) and granulosa layer of the primary and secondary follicles (thick arrows). $\mathrm{C}, \mathrm{G}, \mathrm{K}, \mathrm{O}$ - numerous apoptotic cells in the preantral and antral follicles. D, H, L, P-abundant apoptotic cells in the granulosa of preovulatory follicles. Symbols: a - antrum, at - atretic follicle, $g$ - granulosa, o - oocyte, $s$ - stroma, $t$ - theca. Scale bar: $50 \mu \mathrm{m}$ 
showed follicles no TUNEL immunoreactivity in oocytes (Figure $3 \mathrm{~A}$ ). In primary and secondary follicles, apoptotic cells were present in granulosa layers, but no TUNEL staining was observed in the oocyte nuclei (Figure 3B). Rare apoptotic cells were localized in the preantral and antral follicles (Figure $3 \mathrm{C})$. Numerous apoptotic cells were found in the granulosa layer of preovulatory follicles, but there was still no TUNEL immunoreactivity in oocytes. Apoptotic cells were also rare in the theca layer of preovulatory follicles (Figure 3D). The progress of atretic changes in the follicles was accompanied by increases in the number of apoptotic granulosa and theca cells.

The number of TUNEL-positive cells in the ovary differed among treatment groups. Thus, TUNEL-positive cells were more numerous in the $\mathrm{T}-2$ toxin-treated group (Figure $3 \mathrm{E}-\mathrm{H}$ ) than in the control group (Figure 3A-D), quercetin-treated group (Figure 3I-L), and T-2 toxin + quercetin-treated group (Figure 3M-P). A lower number of apoptotic cells in the follicles was observed in the quercetin-treated group in comparison with the control (Figure 3I-L). There were no variations in TUNEL immunoreactivity in follicles when comparing the T-2 toxin + quercetin-treated group (Figure $3 \mathrm{M}-\mathrm{P}$ ) with the control group.

The number of apoptotic cells per unit area (50 $\times 50 \mu \mathrm{m})$ of ovarian stroma in the examined groups, presented in Figure 4, was comparable to the number of TUNEL-positive cells in the ovarian follicles.

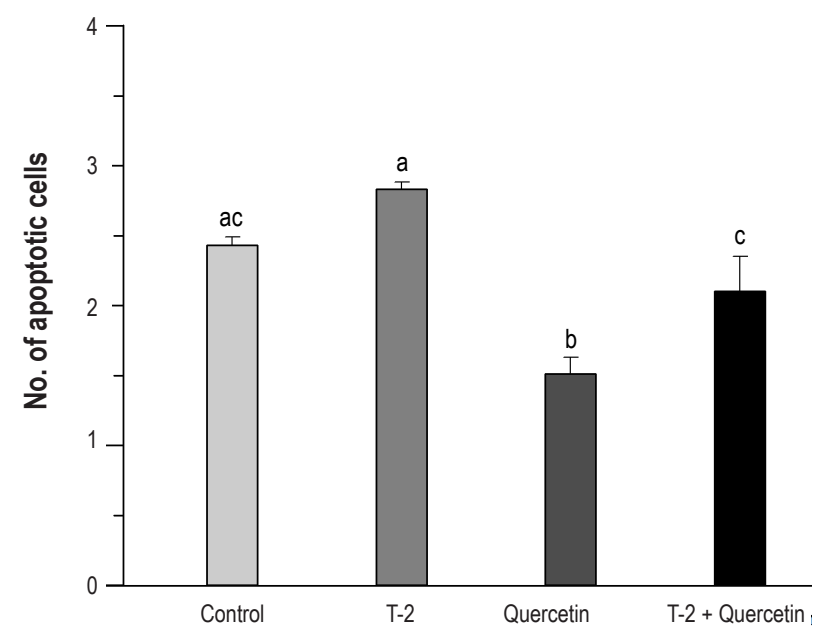

Figure 4. Effect of T-2 toxin and quercetin on number of apoptotic cells in the ovarian stroma. Each value represents the mean \pm SEM from 5 rabbits; values with different superscript letters differ significantly $(p<0.05)$

\section{Discussion}

The ovary is considered a major target of xenobiotics that affect female fertility (Craig et al., 2011; Perera and Herbstman, 2011; Fowler et al., 2012). It has been well established that mycotoxin exposure alters granulosa cell steroid hormone production (Caloni et al., 2009), oocyte development (Minervini et al., 2001; Alm et al., 2006), ovulation (Kumagai and Shimizu, 1982) and pregnancy outcome (D'Mello et al., 1999). In the present study it was found that $\mathrm{T}-2$ toxin decreased the number of proliferating cells in the rabbit ovary. This observation is in accordance with the previously demonstrated dose-related inhibitory effect of T-2 toxin on granulosa cell proliferation in pigs (Caloni et al., 2009). It was also observed that T-2 toxin-treated rats exhibited significantly lower granulosa cell protein levels (Miller-Patrick et al., 1988). In the study of Vanyi et al. (1994) $\mathrm{T}-2$ toxin administration resulted in disruption of follicle maturation and in follicle degeneration in geese. An inhibitory effect of T-2 toxin on cell proliferation was also observed in previous in vitro studies with non-ovarian tissues. Namely, Vlata et al. (2005) demonstrated that $10 \mathrm{ng} \cdot \mathrm{ml}^{-1}$ of T-2 toxin totally inhibited phytohaemagglutinin induced Tlymphocyte proliferation and caused early apoptosis. Minervini et al. (2005) also observed immunotoxic effects of T-2 toxin as measured by cytotoxicity and inhibition of cell proliferation. The concentrations leading to a $50 \%$ inhibition of cell proliferation were 3 and $0.02 \mathrm{ng} \cdot \mathrm{ml}^{-1}$ in MOLT-4 and IM-9 cells, respectively. Similarly, Jaradat et al. (2006) reported that T-2 toxin inhibited mitogen-stimulated chicken lymphocyte proliferation in vitro at concentrations of $1 \mathrm{ng}$. $\mathrm{ml}^{-1}$ or higher. More recently, the mechanisms of inhibition of cell proliferation by T-2 toxin were suggested. Using yeast DNA microarrays Iwahashi et al. (2008) noted T-2 toxin induced cell-cycle arrest, decreased DNA repair system and inhibited synthesis and processing of ribosomea. The authors demonstrated evidence of strong proliferation control due to cell-cycle arrest with induction of MAPK signaling pathway genes induced by the toxicity of the T-2 toxin. In accordance with the previous reports our study suggests that a single dose of T-2 toxin may impair rabbit reproductive function via affecting ovarian cell proliferation.

The next finding of the study was the stimulatory effect of chronic exposure to quercetin on ovarian cell proliferation in rabbits. Our results correspond with the findings of other authors. Immunohistochemical analysis performed by Shu et al. (2011) 
showed that quercetin effectively increased the percentage of proliferating cells in all kinds of follicles in mice. An oestrogen-like effect of quercetin on ovarian development in mice, as measured by increased ovarian organ index and significant changes of plasma FSH and LH levels, has also been demonstrated (Shu et al., 2011). Thus, chronic exposure to quercetin could obviously alter important ovarian processes in animals, and the possible reproductive impact of the flavonoid should be carefully considered in animal nutrition.

Quercetin is among a large number of flavonoid compounds that exert manifold biological effects. It is assumed to possess anti-inflammatory properties, inhibit NADPH oxidase in neutrophils and decrease spontaneous lipid peroxidation. Chen et al. (2012) found that quercetin prevented nickel-induced cell proliferation arrest and death, showed reactive oxygen species (ROS) scavenging activity, and significantly decreased nickel-induced histone hypoacetylation. Our observations additionally indicate that quercetin protects against T-2 toxin-induced ovarian cell proliferation arrest, however, the mechanism of action should be further elucidated.

The results of the present study show that a single dose of T-2 toxin $\left(0.08 \mathrm{mg} \cdot \mathrm{kg}^{-1} \mathrm{BW}\right)$ slightly, but not significantly, increased the number of apoptotic cells in the rabbit ovary. The effective dose for induction of cell apoptosis in vivo is probably higher than that for inhibition of proliferation. In our study, the dose of T-2 toxin was low and close to the natural exposure to $\mathrm{T}-2$ toxin in rabbit feed. According to the results of Tornyos et al. (2011), it seems that adult male rabbits may tolerate a concentration of $0.05 \mathrm{mg} \mathrm{T}-2$ toxin per animal per day. Nonetheless, a daily dose of $0.1 \mathrm{mg}$ and $0.2 \mathrm{mg}$ T-2 toxin significantly diminished feed intake and, in the animals treated with $0.2 \mathrm{mg}$ per animal per day of the mycotoxin, the ratio of spermatozoa with cytoplasmic droplets increased by $320 \%$. Exposure to $0.1 \mathrm{mg}$ per animal per day of the toxin resulted in slight hyperplasia of the Leydig cells. Zwierzchowski et al. (2005) showed that a low dose of another trichothecene, zearalenone, caused disturbances in the development and maturation of some of the best developed ovarian follicles in gilts and suggested that activation of apoptosis of the granulosa cells is responsible for this phenomenon. T-2 toxin has been claimed to cause a wide range of toxic effects in animal cells. Recent data indicate that $\mathrm{T}-2$ toxin induces apoptosis and, in some cell types, necrosis, as well as lipid peroxidation affecting cell membrane integrity. The mechanism of T-2 toxin-induced apoptosis is still controversial and several hy- potheses have been proposed (Jaradat, 2005). DNA damage could be a secondary effect of protein synthesis inhibition or oxidative stress that can, in turn, activate mitochondrial pathways of apoptosis. When $\mathrm{T}-2$ toxin was used at concentrations ranging from 3 to $250 \mathrm{ng} \cdot \mathrm{ml}^{-1}$, apoptosis was associated with DNA fragmentation and activation of several molecules such as caspases-9, -3 and -7 (Minervini et al., 2005; Chaudhari et al., 2009). Increases in Fas, p53, and the expression of the pro-apoptotic Bax protein, and a decline in the expression of the anti-apoptotic protein, Bcl-xL, were observed in a dose-dependent manner after exposures to $1 \sim 20 \mathrm{ng} \cdot \mathrm{ml}^{-1}$ of T-2 toxin (Chen et al., 2008). Alternatively, apoptotic cell death could be due to the induction of stressactivated protein kinase (SAPK/JNK) and mitogen-activated protein kinase (p38/MAPK), either as a secondary effect of protein inhibition or indirectly through lipid peroxidation with ROS production. It is well documented that T-2 toxin and other trichothecenes induce ribotoxic stress responses in different tissues (Shifrin et al., 1999; Rocha et al., 2005). T-2 toxin has been reported to cause dose-dependent inhibition of growth of ovarian granulosa cells in rats by inducing apoptosis and increasing ROS (Wu et al., 2011), but subsequent studies will be required to ascertain whether T-2 toxin alters apoptosis in rabbit granulosa cells.

In the current study, chronic quercetin administration significantly decreased the number of apoptotic cells in the rabbit ovary. Quercetin is assumed to protect DNA, proteins and lipids from oxidative damage, thus exerting a beneficial physiological effect. On the other hand, quercetin is a flavonoid with anti-cancer properties and has been suggested to induce apoptosis in several cancer cell lines (Granado-Serrano et al., 2006; Chou et al., 2010). Interestingly, Samuel et al. (2010) reported that although it induced cell death in a dose-dependent manner, 12.5$50 \mu \mathrm{M}$ quercetin had the ability to inhibit the activity of microtubule-targeting drugs to induce $\mathrm{G} 2 / \mathrm{M}$ arrest in various cell lines. Quercetin has also partially restored drug-induced loss in viability of treated cells (Samuel et al., 2010). The mechanism of action of quercetin should be further elucidated, however.

Our results also indicate a possible protecting effect of quercetin against T-2 toxin-induced ovarian cell apoptosis. Similar results were obtained by other authors. An in vitro study (Markham et al., 1986) on thymocytes revealed that quercetin offered significant protection against cytotoxicity of $\mathrm{T}-2$ toxin by reducing mortality. This protection was greatest when the drug was added before or at the same time as T-2 mycotoxin to the thymocyte 


\section{Conclusions}

In summary, the results of the present study showed that: 1. a single dose of T-2 toxin may impair ovarian cell proliferation, 2. chronic exposure to quercetin caused an increase in ovarian cell proliferation and a decline in cell apoptosis, and 3. quercetin has the potential to attenuate T-2 toxin-induced proliferation arrest. To clarify the mechanism of T-2 toxin and quercetin action in the rabbit ovary, further experiments are necessary.

\section{Acknowledgements}

The paper was supported by Project no. DS3243/KFiEZ, Projects no. 1/0790/11, 1/0084/12, and 1/0022/13 from the Ministry of Education, Science, Research and Sport of the Slovak Republic, and RGB-Net (COST Action TD1101).

\section{References}

Albarenque S.M., Doi K., 2005. T-2 toxin-induced apoptosis in rat keratinocyte primary cultures. Exp. Mol. Pathol. 78, 144-149

Alm H., Brüssow K.P., Torner H., Vanselow J., Tomek W., Dänicke S. Tiemann U., 2006. Influence of Fusarium-toxin contaminated feed on initial quality and meiotic competence of gilt oocytes. Reprod. Toxicol. 22, 44-50

Caloni F., Ranzenigo G., Cremonesi F., Spicer L.J., 2009. Effects of a trichothecene, T-2 toxin, on proliferation and steroid production by porcine granulosa cells. Toxicon $54,337-344$

Chaudhari M, Jayaraj R., Bhaskar A.S.B., Lakshmana Rao P.V., 2009. Oxidative stress induction by $\mathrm{T}-2$ toxin causes DNA damage and triggers apoptosis via caspase pathway in human cervical cancer cells. Toxicology 262, 153-161

Chen J., Cao J., Chu Y., Wang Z, Yang Z., Wang H., 2008. T-2 toxininduced apoptosis involving Fas, p53, Bcl-xL, Bcl-2, Bax and caspase-3 signaling pathways in human chondrocytes. J. Zhejiang Univ. Sci. B 9, 455-463

Chen J., Han J., Wang J., 2012. Prevention of cytotoxicity of nickel by quercetin: the role of reactive oxygen species and histone acetylation. Toxicol. Ind. Health. doi:10.1177/ 0748233711433940

Choi J.S., Li X., 2005. Enhanced diltiazem biovailability after oral administration of diltiazem with quercetin to rabbits. Int. J. Pharm. 297, 1-8

Chou C.C., Yang J.S., Lu H.F., Ip S.W., Lo C., Wu C.C., Lin J.P., Tang N.Y., Chung J.G., Chou M.J., Teng Y.H., Chen D.R., 2010. Quercetin-mediated cell cycle arrest and apoptosis involving activation of a caspase cascade through the mitochondrial pathway in human breast cancer MCF-7 cells. Arch. Pharm. Res. 33, 1181-1191

Craig Z.R., Wang W., Flaws J.A., 2011. Endocrine-disrupting chemicals in ovarian function: effects on steroidogenesis, metabolism and nuclear receptor signaling. Reproduction 142, 633-646

D’Mello J.P.F., Placinta C.M., Macdonald A.M.C., 1999. Fusarium mycotoxins, a review of global implications for animal health, welfare and productivity. Anim. Feed Sci. Tech. 80, 183-205
DeLoach J.R., Gyongyossy-Issa M.I., Khachatourians G.G., 1989. Species-specific hemolysis of erythrocytes by $\mathrm{T}-2$ toxin. Toxicol. Appl. Pharmacol. 97, 107-112

Erlund I., 2004. Review of the flavonoids quercetin, hesperetin, and naringenin. Dietary sources, bioavailability, and epidemiology. Nutr. Res. 24, 851-874

Fowler P.A., Bellingham M., Sinclair K.D., Evans N.P., Pocar P., Fischer B., Schaedlich K., Schmidt J.S., Amezaga M.R., Bhattacharya S., Rhind S.M., O'Shaughnessy P.J., 2012. Impact of endocrine-disrupting compounds (EDCs) on female reproductive health. Mol. Cell. Endocrinol. 355, 231-239

Granado-Serrano A.B., Martín M.A., Bravo L., Goya L., Ramos S., 2006. Quercetin induces apoptosis via caspase activation, regulation of bcl-2, and inhibition of PI-3-Kinase/Akt and ERK pathways in a human hepatoma cell line (HepG2). J. Nutr. 136, 2715-2721

Hrabia A., Sechman A., Gertler A., Rząsa J., 2011. Effect of growth hormone on steroid content, proliferation and apoptosis in the chicken ovary during sexual maturation. Cell Tissue Res. 345, 192-202

Huang P., Akagawa K., Yokoyama Y., Nohara K., Kano K., Morimoto K., 2007. T-2 toxin initially activates caspase-2 and induces apoptosis in U937 cells. Toxicol. Lett. 170, 1-10

Iwahashi Y., Kitagawa E., Iwahashi H., 2008. Analysis of mechanisms of T-2 toxin toxicity using yeast DNA microarrays. Int. J. Mol. Sci. 9, 2585-2600

Jaradat Z.W., 2005. T-2 mycotoxin in the diet and its effects on tissues. Food Nutr. Toxic. 4, 173-212

Jaradat Z.W., Viia B., Marquardt R.R., 2006. Adverse effects of T-2 toxin on chicken lymphocytes blastogenesis and its protection with Vitamin E. Toxicology. 225, 90-96

Knab A.M., Shanely R.A., Jin F., Austin M.D., Sha W., Nieman D.C., 2011. Quercetin with vitamin $C$ and niacin does not affect body mass or composition. Appl. Physiol. Nutr. Metab. 36, 331-338

Kosuri N.R., Smalley E.B., Nichols R.E., 1971. Toxicologic studies of Fusarium tricinictum (corda) Snyder et Hansen from moldy corn. Amer. J. Vet. Res. 32, 1843-1850

Kumagai S., Shimizu T., 1982. Neonatal exposure to zearalenone causes persistent anovulatory estrus in the rat. Arch. Toxicol. 50, 279-286

Labuda R., Parich A., Vekiru E., Tancinova D., 2009. Incident of fuminosis, moniliformin and Fusarium species in poultry feed mixtures from Slovakia. Ann. Agr. Environ. Med. 12, 81-86

Markham R.J.F., Erhardt N.P., Dininno V.L., Penman D., Bhatti A.R., 1986. Flavonoids protect against T-2 mycotoxins both in vitro and in vivo. J. Gen. Microbiol. 133, 589-592

Miller-Patrick K., Ballough G.P., Wickersham E.W., Anthony A., 1988. Cytophotometric assessment of granulosa cell protein and nucleic acid levels during they estrous cycle in rats treated with T-2 toxin. Life Sci. 43, 2231-2239

Minervini F., Del'Aquila M.E., Maritano P., Minoia P., Visconti A., 2001. Toxic effects of the mycotoxin zearalenone and its derivatives on in vitro maturation of bovine oocytes and $17 \mathrm{~b}$-estradiol I evels in mural granulosa cell cultures. Toxicol. Vitro 15, 489-495

Minervini F., Fornelli F., Lucivero G., Romano C., Visconti A., 2005. T-2 toxin immunotoxicity on human $B$ and $T$ lymphoid cell lines. Toxicology 210, 81-91 
Pestka J.J., 2007. Deoxynivalenol: Toxicity, mechanisms and animal health risks. Anim. Feed Sci. Tech. 137, 283-298

Petruska P., Capcarova M., 2012. Effect of chronic application of quercetin and acute dose of T-2 toxin on hematological parameters of rabbits. MendelNet. Brno. Conference materials, pp. 981-988

Perera F., Herbstman J., 2011. Prenatal environmental exposures, epigenetics, and disease. Reprod. Toxicol. 31, 363-373

Rocha O., Ansari K., Doohan F.M., 2005. Effects of trichothecene mycotoxins on eukaryotic cells: a review. Food Addit. Contam. 22, 369-378

Samuel T., Fadlalla K., Turner T., Yehualaeshet T.E., 2010. The flavonoid quercetin transiently inhibits the activity of taxol and nocodazole through interference with the cell cycle. Nutr. Cancer 62, 1025-1035

Sehata S., Kiyosawa N., Atsumi F., Ito K., Yamoto T., Teranishi M., Uetsuka K., Nakayama H., Doi K., 2005. Microarray analysis of T-2 toxin-induced liver, placenta and fetal liver lesions in pregnant rats. Exp. Toxicol. Pathol. 57, 15-28

Shifrin V.I., Anderson P., 1999. Trichothecene mycotoxins trigger a ribotoxic stress response that activates c-Jun N-terminal kinase and p38 mitogen-activated protein kinase and induces apoptosis. J. Biol. Chem. 274, 13985-13992

Shu X., Hu X.J., Zhou S.Y., Xu C.L., Qiu Q.Q., Nie S.P., Xie M.Y., 2011. Effect of quercetin exposure during the prepubertal period on ovarian development and reproductive endocrinology of mice. Yao Xue Xue Bao 46, 1051-1057

Sudakin D.L., 2003. Trichothecenes in the environment: relevance to human health. Toxicol. Lett. 143, 97-107

Szilágyi M., Fekete S., Huszenicza G.Y., Albert M., 1994. Biochemical and physiological effects of long-term sublethal T-2 toxin feeding in rabbits. Acta Biol. Hung. 45, 69-76
Tancinova D., Labuda R., 2009. Fungi on wheat bran and their toxinogenity. Ann. Agr. Environ. Med. 16, 325-331

Tiemann U., Viergutz T., Jonas L., Schneider F., 2003. Influence of the mycotoxins alpha- and beta-zearalenol and deoxynivalenol on the cell cycle of cultured porcine endometrial cells. Reprod. Toxicol. 17, 209-218

Tornyos G., Cseh S., Matics Z., Kametler L., Rajli V., Bodnar Z., Rusvai M., Mandoki M., Kovacs M., 2011. Preliminary results on the effect of chronic T-2 toxin exposure in rabbit bucks. Agr. Conspec. Sci. 76, 369-372

Ványi A., Glávits R., Bata A., Kovács F., 1994. Pathomorphological changes caused by T-2 trichothecene fusariotoxin in geese. Acta Vet. Hung. 42, 447-457

Vlata Z., Porichis F., Tzanakakis G., Tsatsakis A., Krambovitis E., 2005. In vitro cytopathic effects of mycotoxin T-2 on human peripheral blood T lymphocytes. Toxicol. Lett. 160, 60-68

Weaver G.A., Kurtz H.J., Mirocha C.J., Bates F.Y., Behrens J.C., Robinson T.S., Gipp W.F., 1978. Mycotoxin-induced abortions in swine. Can. Vet. J. 19, 72-74

Witt M.F., Pestka J.J., 1990. Uptake of the naturally occurring 3-alpha-hydroxy isomer of T-2 toxin by a murine $B$ cell hybridoma. Food Chem. Toxicol. 28, 21-28

Wu J., Jing L., Yuan H., Peng S.Q., 2011. T-2 toxin induces apoptosis in ovarian granulosa cells of rats through reactive oxygen species-mediated mitochondrial pathway. Toxicol. Lett. 202, 168-177

Zwierzchowski W., Przybyłowicz M., Obremski K., Zielonka L., Skorska-Wyszyńska E., Gajecka M., Polak M., Jakimiuk E., Jana B., Rybarczyk L., Gajecki M., 2005. Level of zearalenone in blood serum and lesions in ovarian follicles of sexually immature gilts in the course of zearalenone micotoxicosis. Pol. J. Vet. Sci. 8, 209-218 